\title{
Role of monoamine-oxidase-A-gene variation in the development of glioblastoma in males: a case control study
}

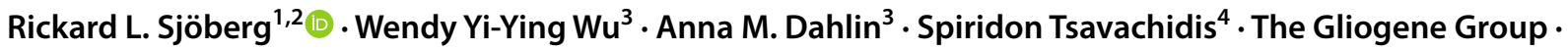 \\ Melissa L. Bondy ${ }^{4} \cdot$ Beatrice Melin ${ }^{3}$
}

Received: 1 August 2019 / Accepted: 16 September 2019 / Published online: 25 September 2019

(c) The Author(s) 2019

\begin{abstract}
Background The Mono-amine oxidase-A (MAO-A) enzyme is involved in the degradation and regulation of catecholamines such as serotonin, dopamine, epinephrine and nor-epinephrine. Preclinical studies suggest that this enzyme may contribute to an environment favorable for growth of malignant glioma. The $M A O-A$ gene is located on the $\mathrm{X}$-chromosome and has at least one functional genetic polymorphism. The aim of the present study was to explore possible effects of $M A O-A$ genotype on development of glioblastoma in males.

Methods Genotypes for 437 glioma cases and 876 population-based controls from the Swedish Glioma International CaseControl study (GICC) were compared. We analyzed the germline DNA using the Illumina Oncoarray. We selected seven single nucleotide polymorphisms (SNPs) located in the MAO-A gene, and imputed genotypes based on data from the 1000 genomes project. We used 1579 male glioblastoma cases and 1875 controls comprising the whole GICC cohort for subsequent validation of findings.

Results The rs 144551722 SNP was a significant predictor of development of glioblastoma in males ( $\mathrm{p}$-value $=0.0056$ ) but not in females even after correction for multiple testing. We conducted haplotype analysis to confirm an association between $M A O-A$ gene and risk of glioblastoma (p-value $=0.016$ ). We found similar results in the validation sample.

Conclusions These results suggest the possibility of a role for the MAO-A enzyme and the MAO-A gene in the development of glioblastoma in males.
\end{abstract}

Keywords MAOA genetics glioblastoma males

\section{Introduction}

The risk for developing glioma is roughly 1.4 times greater for males than females $[1,2]$. We have recently described 25 genetic variants associated with development of glioma in

Rickard L. Sjöberg

Rickard.sjoberg@umu.se

1 Department of Clinical Science, Neuroscience, Umeå University, Umeå, Sweden

2 Department of Neurosurgery, University Hospital of Northern Sweden, 90185 Umeå, Sweden

3 Department of Radiation Sciences, Oncology, Umeå University, Umeå, Sweden

4 Department of Medicine, Section of Epidemiology and Population Sciences, Dan L. Duncan Comprehensive Cancer Center, Baylor College of Medicine, Houston, TX, USA both genders using a genome wide approach [3]. In addition, a recent study using a similar approach but focusing on the $\mathrm{X}$-chromosome identified four regions of potential interest that remained statistically significant after correction for 250,000 significance tests [4]. In these studies, an agnostic, exploratory methodology was applied, according to which all available polymorphisms were analyzed, regardless of known function.

However, a potential useful alternative strategy in the study of genetically determined sex differences is the candidate gene study. In this context such a strategy might mean focusing on known $\mathrm{x}$-linked genetic polymorphisms that, for theoretical reasons, might be expected to be related to glioma development.

One such candidate is the $M A O-A$-gene that is located on the X-chromosome (Xp 11.23) [5]. The gene codes for a protein that is involved in the degradation of several neurotransmitters most important serotonin, dopamine, epinephrine 
and nor-epinephrine in a tissue specific manner. Functional variations in the $M A O$ - $A$-gene have in several studies been associated with behavioral outcomes particularly in males. One early example is a study of a Dutch family, in which a stop codon in the gene, associated with severe antisocial behavior in males, was identified [6]. More recently much interest has been focused on a functional variable number of tandem repeat (VNTR-)polymorphism in the promoter region of the $M A O-A$ gene commonly referred to as the MAOA-Linked Polymorphic Region (MAOA-LPR) [7, 8]. The low function variant of this VNTR has in several studies been linked to behavioral and neurophysiological phenotypes in males, [9-14] and to some lesser extent females [15, 16]. This has led to a common assumption within the field of behavioral genetics that the polymorphism may be important in the overall regulation of monoaminergic systems [17].

From a theoretical point-of-view there are at least three possible mechanisms by which variation in the MAOA-gene may be relevant to the development of glioma. The two first of these would be through the regulation of monoaminergic neurotransmission, particularly Serotonin and Dopamine [18].

\section{Regulation of stem cell proliferation}

It has been reported that both Dopamine and Serotonin influence proliferation of neural progenitor cells in the sub ventricular zone, [19-21] and the dentate gyrus [22], respectively. Converging evidence suggests that the cells that give rise to glioma development may share many important features with these progenitor cells [23, 24] suggesting the possibility that Dopamine and Serotonin may influence cell proliferation in glioma precursor cells as well. This would provide potential for functional genetic variation in a gene relevant to the regulation of these neurotransmitters to influence early glioma development.

\section{Regulation of angiogenesis}

Particularly Dopamine has in several studies been implicated as an inhibitor of angiogenesis through interaction with the Vascular endothelial growth factor (VEGF) pathway [25, 26]. Since angiogenesis is a key feature of glioma development, particularly in glioblastoma, a genetic polymorphism with the potential to regulate levels of an endogenous inhibitor of angiogenesis may also be a possible candidate gene.

\section{Effects of oxidative stress}

Findings of increased serum levels of reactive oxygen species (ROS) in patients who later develop Glioblastoma suggests a role for oxidative stress in the genesis of this disease [27]. Levels of oxidative stress including increased ROS has been associated with MAO-A over-expression in prostate cancer models $[28,29]$. Therefore, it would seem to make sense that a functional polymorphism that regulates MAO-A transcription could influence levels of oxidative stress in a way that might influence glioma development.

More direct experimental evidence for a role of the MAO-A enzyme in glioma development was recently provided in experiments reported by Kushal et al. [30]. These authors found increased levels of the MAO-A protein in glioma tissue. Furthermore, they found that inhibition of MAO-A activity was cytotoxic to glioma cells in-vitro and that it reduced proliferation, microvessel density, and invasion of glioma tissue in a rat model.

In line with the reasoning presented above, the purpose of the present study was to investigate the specific hypothesis that variation in the MAOA gene is associated with development of glioblastoma in males. We investigated this hypothesis using a case-control approach.

\section{Methods}

\section{Swedish sample}

The study subjects included in the risk analysis were those who participated in the Swedish Glioma International Case-Control (GICC) study. Details of patient recruitment, data collection, and quality control are available in previous publications [3, 31]. In brief, cases were between the ages of $18-80$ years, and recruited between the years 2010 and 2013 from five hospitals in Sweden. In total, 472 histologically confirmed newly diagnosed glioma cases and 908 population-based controls were genotyped. We excluded subjects with $<99 \%$ sample genotyping call-rate, subjects with inconsistencies between reported sex and sex estimated by genotype, subjects with $<80 \%$ estimated European ancestry, subjects identified as outliers in principle component analyses and one of each pair of individuals with spurious relations (PI-HAT > 0.2). We also excluded cases with rare glioma diagnoses (SNOMED codes 93913, 93923, 94121, 94211, 94423, and 95051). After this quality control, 437 cases and 876 controls were included. There were 175 male and 94 female GBM cases.

\section{SNP selection}

We selected seven SNPs in the MAO-A gene. Because MAO-LPR was not directly sequenced in our study, we used Haploview (version 4.2) to select 3 SNPs with minor allele frequency $>0.1$ that tag variation in the region of the MAO-LPR. For this purpose, we used reference data $( \pm 10 \mathrm{~kb}$ from MAO-LPR) from the 1000 genomes 
projects (phase 3, European population) [32]. Details of the analyzed SNPs are shown in Table 1.

\section{Genotyping and imputation}

We used the Illumina Oncoarray to genotype the SNPs. We imputed untyped variants in the MAOA gene using the IMPUTE2 and SHAPEIT2 software, and data from the 1000 genomes project as reference [33-36]. Before imputation, we excluded SNPs with poor call-rate $(<95 \%)$, p-value from Hardy-Weinberg test $<1 \times 10^{-6}$, minor allele frequency $<0.01$, and all $\mathrm{A} / \mathrm{T}$ and $\mathrm{C} / \mathrm{G}$ SNPs. Imputation info scores for SNPs in MAO-A are presented in Table 1. For imputed variants, genotypes were called based on the highest imputed genotype probability. A genotype call was set to "missing" in subjects where all three genotype probabilities for a variant were $<0.9$.

\section{Statistical analysis}

We performed gender-stratification analyses to test the associations between genotype/allele frequencies and glioma risk using chi-square test/Fisher exact test. We conducted haplotype analysis of 5 SNPs in the MAO-A gene, and logistic regression to estimate odds ratios (OR) and $95 \%$ confidence intervals (CI). We applied Bonferroni correction for the SNP-analysis by setting the critical $p$ level to $0.00714(005 / 7)$.

\section{Validation set}

The cases and controls from the entire GICC study earlier presented was used for validation [31]. In total there were 2614 male glioma cases, of whom 1579 was glioblastoma. They were compared to 1875 male controls.

\section{Results}

\section{Analysis of the Swedish sample}

\section{SNP-analysis}

Table 2 describes analyses of association between the seven selected SNPs in male cases and controls, and the p-values were $<0.05$ for all seven SNPs. After correction for multiple testing the rs 144551722 SNP remained significant $(p$-value $=0.0056)$. There were no significant effects for lower grade gliomas or glioblastomas (as can be seem in Table 3), for females.

\section{Haplotype analysis}

Second, a haplotype analysis including rs 144551722 , rs 1465108 , rs909525, rs979605, rs2239448 was performed in order to further investigate the relation between genotype and glioblastoma in males. The overall haplotype pattern was, as seen in Table 4, significant ( $p$-value $=0.016$ ).

\section{Validation in the whole GICC cohort}

\section{SNP-analysis}

After analyses of the Swedish sample, we conducted a validation analysis on the whole GICC cohort. As can be seen in Table 5, rs144551722, which was the only SNP to remain statistically significant after correction for multiple testing in the Swedish dataset, was significant in the whole GICC cohort as well $(\mathrm{p}<0.05)$.

\section{Haplotype analysis}

As seen in Table 6 a replication of the haplotype analysis in the full GICC case control did not reach significance $(\mathrm{p}$-value $=0.1)$.
Table 1 Analyzed SNPs in the $M A O-A$ gene

\begin{tabular}{llllll}
\hline SNP numbers & Location & Most severe consequence & Alleles & Info & Certainty \\
\hline rs5905513 & 43491842 & Intergenic variant & G/A & 0.837 & 0.925 \\
rs144551722 & 43491877 & Intergenic variant & G/A & 0.784 & 0.948 \\
rs5906260 & 43498619 & Intergenic variant & $\mathrm{C} / \mathrm{T}$ & 0.998 & 0.999 \\
rs1465108 & 43538209 & Intron variant & $\mathrm{A} / \mathrm{G}$ & 0.995 & 0.998 \\
rs909525 & 43553202 & Intron variant & $\mathrm{C} / \mathrm{T}$ & 0.978 & 0.991 \\
rs979605 & 43601363 & Intron variant & $\mathrm{A} / \mathrm{G}$ & 0.999 & 1 \\
rs2239448 & 43602679 & Intron variant & T/C & 0.999 & 1 \\
\hline
\end{tabular}


Table 2 Association of MAO-A polymorphisms in Swedish 770 males
Table 3 Association of MAO-A polymorphisms in Swedish 530 females

\begin{tabular}{|c|c|c|c|c|c|c|c|c|c|}
\hline \multirow[t]{2}{*}{ SNP } & & \multicolumn{2}{|c|}{$\begin{array}{l}\text { Control } \\
(\mathrm{N}=516)\end{array}$} & \multicolumn{2}{|c|}{$\begin{array}{l}\text { GBM case } \\
(\mathrm{N}=175)\end{array}$} & \multicolumn{2}{|c|}{$\begin{array}{l}\text { Non GBM } \\
\text { case }(\mathrm{N}=79)\end{array}$} & \multirow[t]{2}{*}{$\mathrm{p}$ Value for GBM } & \multirow[t]{2}{*}{$\begin{array}{l}\mathrm{p} \text { Value for } \\
\text { non GBM }\end{array}$} \\
\hline & & $\mathrm{N}$ & $(\%)$ & $\mathrm{N}$ & $(\%)$ & $\mathrm{N}$ & $(\%)$ & & \\
\hline \multirow[t]{2}{*}{ rs5905513 } & A & 211 & $(48.96)$ & 84 & $(61.31)$ & 28 & $(43.75)$ & \multirow[t]{2}{*}{0.0154} & \multirow[t]{2}{*}{0.5198} \\
\hline & G & 220 & $(51.04)$ & 53 & $(38.69)$ & 36 & $(56.25)$ & & \\
\hline \multirow[t]{2}{*}{ rs144551722 } & G & 392 & $(87.89)$ & 148 & $(96.10)$ & 65 & $(94.20)$ & \multirow[t]{2}{*}{0.0056} & \multirow[t]{2}{*}{0.1807} \\
\hline & A & 54 & (12.11) & 6 & $(3.90)$ & 4 & $(5.80)$ & & \\
\hline \multirow[t]{2}{*}{ rs5906260 } & $\mathrm{T}$ & 337 & (65.31) & 134 & (76.57) & 54 & $(68.35)$ & \multirow[t]{2}{*}{0.0076} & \multirow[t]{2}{*}{0.6865} \\
\hline & $\mathrm{C}$ & 179 & $(34.69)$ & 41 & $(23.43)$ & 25 & $(31.65)$ & & \\
\hline \multirow[t]{2}{*}{ rs1465108 } & G & 333 & $(64.91)$ & 133 & $(76.00)$ & 53 & $(67.09)$ & \multirow[t]{2}{*}{0.0089} & \multirow[t]{2}{*}{0.8017} \\
\hline & A & 180 & $(35.09)$ & 42 & $(24.00)$ & 26 & $(32.91)$ & & \\
\hline \multirow[t]{2}{*}{ rs909525 } & $\mathrm{T}$ & 317 & $(62.52)$ & 128 & $(73.56)$ & 52 & $(66.67)$ & \multirow[t]{2}{*}{0.0108} & \multirow[t]{2}{*}{0.5621} \\
\hline & $\mathrm{C}$ & 190 & $(37.48)$ & 46 & $(26.44)$ & 26 & $(33.33)$ & & \\
\hline \multirow[t]{2}{*}{ rs979605 } & G & 340 & $(65.89)$ & 133 & $(76.00)$ & 54 & $(68.35)$ & \multirow[t]{2}{*}{0.0167} & \multirow[t]{2}{*}{0.7617} \\
\hline & A & 176 & (34.11) & 42 & $(24.00)$ & 25 & (31.65) & & \\
\hline \multirow[t]{2}{*}{ rs2239448 } & $\mathrm{C}$ & 339 & $(65.70)$ & 133 & $(76.00)$ & 54 & $(68.35)$ & \multirow[t]{2}{*}{0.0148} & \multirow[t]{2}{*}{0.7363} \\
\hline & $\mathrm{T}$ & 177 & $(34.30)$ & 42 & $(24.00)$ & 25 & $(31.65)$ & & \\
\hline
\end{tabular}

Bold is used to highlight significant $p$-values after Bonferroni correction for 7 tests $(p=0.05 / 20=0.0072)$

\begin{tabular}{|c|c|c|c|c|c|c|c|c|}
\hline \multirow[t]{2}{*}{ SNP } & \multicolumn{2}{|c|}{$\begin{array}{l}\text { Control } \\
(\mathrm{N}=360)\end{array}$} & \multicolumn{2}{|c|}{$\begin{array}{l}\text { GBM Case } \\
(\mathrm{N}=94)\end{array}$} & \multicolumn{2}{|c|}{$\begin{array}{l}\text { Non GBM case } \\
(\mathrm{N}=76)\end{array}$} & \multirow[t]{2}{*}{$\mathrm{p}$ Value for GBM } & \multirow[t]{2}{*}{$\begin{array}{l}\mathrm{p} \text { Value for } \\
\text { non GBM }\end{array}$} \\
\hline & $\mathrm{N}$ & $(\%)$ & $\mathrm{N}$ & $(\%)$ & $\mathrm{N}$ & $(\%)$ & & \\
\hline \multicolumn{9}{|c|}{ rs5905513 } \\
\hline AA & 68 & (28.94) & 9 & (16.36) & 15 & $(30.00)$ & 0.0889 & 0.2147 \\
\hline AG & 112 & $(47.66)$ & 27 & $(49.09)$ & 18 & $(36.00)$ & & \\
\hline GG & 55 & $(23.40)$ & 19 & $(34.55)$ & 17 & $(34.00)$ & & \\
\hline \multicolumn{9}{|c|}{ rs 144551722} \\
\hline GG & 230 & (79.04) & 58 & (86.57) & 48 & $(87.27)$ & $0.2769^{*}$ & $0.4147 *$ \\
\hline GA & 58 & (19.93) & 8 & (11.94) & 7 & (12.73) & & \\
\hline AA & 3 & $(1.03)$ & 1 & $(1.49)$ & 0 & $(0.00)$ & & \\
\hline \multicolumn{9}{|c|}{ rs5906260 } \\
\hline TT & 164 & $(45.81)$ & 39 & (41.94) & 38 & $(50.00)$ & 0.2563 & 0.3379 \\
\hline $\mathrm{CT}$ & 161 & (44.97) & 40 & (43.01) & 28 & (36.84) & & \\
\hline $\mathrm{CC}$ & 33 & $(9.22)$ & 14 & $(15.05)$ & 10 & (13.16) & & \\
\hline \multicolumn{9}{|c|}{ rs 1465108} \\
\hline GG & 164 & $(45.81)$ & 38 & $(41.30)$ & 38 & $(50.00)$ & 0.2725 & 0.3759 \\
\hline GA & 160 & $(44.69)$ & 40 & $(43.48)$ & 28 & $(36.84)$ & & \\
\hline AA & 34 & $(9.50)$ & 14 & $(15.22)$ & 10 & (13.16) & & \\
\hline \multicolumn{9}{|c|}{ rs909525 } \\
\hline TT & 149 & (43.06) & 29 & $(32.58)$ & 33 & $(45.21)$ & 0.1544 & 0.4298 \\
\hline $\mathrm{TC}$ & 156 & $(45.09)$ & 45 & $(50.56)$ & 28 & (38.36) & & \\
\hline $\mathrm{CC}$ & 41 & $(11.85)$ & 15 & (16.85) & 12 & (16.44) & & \\
\hline \multicolumn{9}{|c|}{ rs979605 } \\
\hline GG & 180 & $(50.00)$ & 42 & (44.68) & 37 & (48.68) & 0.1812 & 0.8674 \\
\hline GA & 149 & (41.39) & 38 & (40.43) & 31 & (40.79) & & \\
\hline AA & 31 & $(8.61)$ & 14 & (14.89) & 8 & (10.53) & & \\
\hline \multicolumn{9}{|c|}{ rs2239448 } \\
\hline $\mathrm{CC}$ & 180 & $(50.00)$ & 42 & (44.68) & 37 & (48.68) & 0.1812 & 0.8674 \\
\hline $\mathrm{CT}$ & 149 & (41.39) & 38 & $(40.43)$ & 31 & (40.79) & & \\
\hline TT & 31 & $(8.61)$ & 14 & (14.89) & 8 & (10.53) & & \\
\hline
\end{tabular}

*Fisher exact test 
Table 4 Haplotype analysis of 5 SNPs in the MAO-A gene in 154 Swedish males with glioblastoma and 441 controls

\begin{tabular}{|c|c|c|c|c|c|c|c|}
\hline \multirow[t]{2}{*}{ Haplotype $^{a}$} & \multicolumn{2}{|c|}{ Control } & \multicolumn{2}{|c|}{ GBM } & \multirow[t]{2}{*}{ OR } & \multirow[t]{2}{*}{$95 \% \mathrm{CI}$} & \multirow[t]{2}{*}{$\mathrm{p}$ Value } \\
\hline & $\mathrm{N}$ & $(\%)$ & $\mathrm{N}$ & $(\%)$ & & & \\
\hline GGTGC & 303 & (70.6) & 126 & (29.4) & 1.00 & & \\
\hline GGTAT & 12 & (85.7) & 2 & (14.3) & 0.40 & $(0.06,1.50)$ & 0.236 \\
\hline GGCGC & 17 & (77.3) & 5 & (22.7) & 0.71 & $(0.23,1.83)$ & 0.505 \\
\hline GACAT & 56 & (78.9) & 15 & (21.1) & 0.64 & $(0.34,1.15)$ & 0.155 \\
\hline AACGC & 10 & (90.9) & 1 & $(9.1)$ & 0.24 & $(0.01,1.28)$ & 0.176 \\
\hline AACAT & 43 & (89.6) & 5 & (10.4) & 0.28 & $(0.10,0.66)$ & 0.008 \\
\hline
\end{tabular}

${ }^{a}$ SNP numbers: rs 144551722, rs1465108, rs909525, rs979605, rs2239448

Global p-value $=0.016$

\begin{tabular}{|c|c|c|c|c|c|c|c|c|}
\hline \multirow[t]{2}{*}{ SNP } & \multicolumn{2}{|c|}{$\begin{array}{l}\text { Control } \\
(\mathrm{N}=1875)\end{array}$} & \multicolumn{2}{|c|}{$\begin{array}{l}\text { GBM case } \\
(\mathrm{N}=1579)\end{array}$} & \multicolumn{2}{|c|}{$\begin{array}{l}\text { Non GBM Case } \\
(\mathrm{N}=1035)\end{array}$} & \multirow[t]{2}{*}{$\mathrm{p}$ Value for GBM } & \multirow[t]{2}{*}{$\begin{array}{l}\mathrm{p} \text { Value for } \\
\text { non GBM }\end{array}$} \\
\hline & $\mathrm{N}$ & $(\%)$ & $\mathrm{N}$ & $(\%)$ & $\mathrm{N}$ & $(\%)$ & & \\
\hline \multicolumn{9}{|c|}{ rs5905513 } \\
\hline A & 1036 & $(44.7)$ & 913 & $(57.8)$ & 436 & $(42.1)$ & 0.13 & 0.185 \\
\hline G & 839 & $(55.3)$ & 666 & $(42.2)$ & 599 & $(57.9)$ & & \\
\hline \multicolumn{9}{|c|}{ rs 144551722} \\
\hline G & 1520 & $(81.1)$ & 1322 & $(83.7)$ & 851 & $(82.2)$ & 0.0441 & 0.455 \\
\hline A & 355 & $(18.9)$ & 257 & $(16.3)$ & 184 & $(17.8)$ & & \\
\hline \multicolumn{9}{|c|}{ rs5906260 } \\
\hline $\mathrm{T}$ & 1311 & $(69.9)$ & 1122 & $(71.1)$ & 740 & $(71.5)$ & 0.477 & 0.396 \\
\hline $\mathrm{C}$ & 564 & $(30.1)$ & 457 & $(28.9)$ & 295 & $(28.5)$ & & \\
\hline \multicolumn{9}{|c|}{ rs 1465108} \\
\hline G & 1301 & $(69.4)$ & 1115 & $(70.6)$ & 739 & (71.4) & 0.434 & 0.272 \\
\hline A & 574 & $(30.6)$ & 464 & $(29.4)$ & 296 & $(28.6)$ & & \\
\hline \multicolumn{9}{|c|}{ rs909525 } \\
\hline $\mathrm{T}$ & 1235 & $(65.9)$ & 1058 & $(67)$ & 703 & $(67.9)$ & 0.492 & 0.268 \\
\hline $\mathrm{C}$ & 640 & $(34.1)$ & 521 & (33) & 332 & $(32.1)$ & & \\
\hline \multicolumn{9}{|c|}{ rs979605 } \\
\hline G & 1298 & $(69.2)$ & 1105 & (70) & 741 & (71.6) & 0.656 & 0.19 \\
\hline A & 577 & $(30.8)$ & 474 & $(30)$ & 294 & $(28.4)$ & & \\
\hline \multicolumn{9}{|c|}{ rs 2239448} \\
\hline $\mathrm{C}$ & 1299 & (69.3) & 1104 & $(69.9)$ & 295 & $(28.5)$ & 0.711 & 0.22 \\
\hline $\mathrm{T}$ & 576 & $(30.7)$ & 475 & $(30.1)$ & 740 & (71.5) & & \\
\hline
\end{tabular}

Table 5 Association of MAO-A polymorphisms in males in the whole GICC cohort
Table 6 Haplotype analysis of 5 SNPs in the MAO-A gene in 2307 males with glioblastoma and 1850 controls from the whole Glioma International Case-Control (GICC) study

\begin{tabular}{|c|c|c|c|c|c|c|c|}
\hline \multirow[t]{2}{*}{ Haplotype $^{\mathrm{a}}$} & \multicolumn{2}{|c|}{ Control } & \multicolumn{2}{|l|}{ GBM } & \multirow[t]{2}{*}{ OR } & \multirow[t]{2}{*}{$95 \% \mathrm{CI}$} & \multirow[t]{2}{*}{$\mathrm{p}$ Value } \\
\hline & $\mathrm{N}$ & $(\%)$ & $\mathrm{N}$ & $(\%)$ & & & \\
\hline GGTGC & 1169 & (39.7) & 1778 & $(60.3)$ & 1.00 & & \\
\hline GGTAT & 56 & (48.3) & 60 & (51.7) & 0.70 & $(0.48,1.04)$ & 0.067 \\
\hline GGCGC & 66 & $(41.2)$ & 94 & $(58.8)$ & 0.94 & $(0.67,1.31)$ & 0.74 \\
\hline GACAT & 210 & $(39.2)$ & 326 & $(60.8)$ & 1.02 & $(0.84,1.24)$ & 0.848 \\
\hline AACGC & 47 & (49) & 49 & (51) & 0.69 & $(0.45,1.05)$ & 0.072 \\
\hline AACAT & 302 & (42.6) & 407 & (57.4) & 0.89 & $(0.75,1.05)$ & 0.159 \\
\hline
\end{tabular}

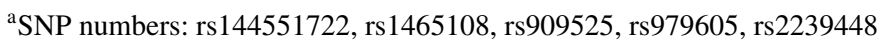

Global p-value $=0.1$ 


\section{Discussion}

The purpose of the present study was to investigate the hypothesis that polymorphisms in the $M A O$ - $A$-gene are associated with development of glioma in males. As described in the introduction there are several theoretical reasons to assume a potential involvement of the MAOA-enzyme in glioma development. However, the direct impetus for performing the study was a recently published series of experiments demonstrating direct effects of the MAOA protein on central features of glioma development [30]. The $M A O-A$-gene is $\mathrm{x}$-linked and variation in the functional $M A O-A-\mathrm{LPR}$ is known to interact with androgens in vitro and in vivo $[12,37]$. Both facts make it reasonable to assume that the effects would be considerably stronger in males.

The results of the present study are generally in line with these predictions. That is one of the SNPs that was selected to tag the genetic region spanning the MAO-LPR (rs144551722) in the present study was significantly associated with glioblastoma in the Swedish sample. A replication study in the full GICC cohort showed weaker findings, but still confirmed an association between glioblastoma and the $\mathrm{G} / \mathrm{C}$ variant of the rs 144551722 .

Taken as a whole our results support the hypothesis that MAOA-genotype may play a role in development of glioblastoma in males. One possible explanation for differences in the strength of results between samples may of course be that the findings are spurious. Among other possible explanations may be that some genetic or environmental risk exposures that interact with the $M A O A$ genotype may be more common amongst Swedes, or differences in the frequency of the genotype in different populations. So for instance, the MAOA-gene particularly the MAOA-LPR is from behavioral genetics studies known for interacting with environmental factors to predict behavioral outcomes. A similar gene by environment interaction effect in predicting glioma development may have had differential effects in the two case-control sets depending on sociocultural conditions. Furthermore, since the MAOA$L P R$ is known to influence behavioral outcomes, behavioral differences may also have shaped environmental exposures differently in the two groups. However, no common environmental agents have consistently been associated with glioma risk, apart from the exposure of high dose ionizing radiation, which is a rare event. In our previous studies, we have observed an association with vitamin $\mathrm{E}$, potentially also mediated by the ROS system, but these finding still need independent validation [31].

One important way of further determining whether the tentative general conclusion of a link between development of glioblastoma in males and the rs 144551722 is valid will of course be further replication studies. Doing so would be important since an association between rs 14551722 and male GBM (as well as a possible association between this disease and $M A O A-L P R$ ) would have at least three potentially significant implications for glioma research.

\section{Understanding of the role of monoaminergic pathways in glioma development}

As discussed in the introduction there is evidence from previous research to suggest that monoaminergic function might be an important factor in shaping the environment in which gliomas thrive [23-30]. There is also additional evidence to suggest that the MAO-A enzyme may be a key player in regulating these systems [21]. One of the most important aspects of a link between glioma development and $M A O$ $A$-genotype is as a validation of this line of inquiry in glioma research.

\section{Strengthening the logic for clinical trials involving MAO-inhibitors}

One possibility suggested by the recent pre-clinical study on glioma development is that MAO-inhibiting drugs might possibly become a useful pharmacological adjunct in the treatment of glioma. A finding of a link between $M A O$ $A$-genotype and development of glioblastoma in the present case-control data sets seems to strengthen the logic in pursuing this possibility further.

\section{The possibility of MAO-A-genotype as a clinical marker}

From a clinical perspective, gliomas share several common features but there are also important individual differences in essential aspects of the disease. That is, there are considerable variations in for instance growth rate, response to therapeutic interventions etc. between individual glioma cases. Although there are some useful molecular markers that may help clinicians make meaningful differentiations between subgroups of gliomas such as $I D H-1$ mutation status most such factors remain unknown. Could MAO-A genotype status eventually prove to be a useful clinical marker in glioma cases? Our study does not provide an answer to this question but does suggest that further investigation of this possibility in future studies might be meaningful.

As described above both a strength and a weakness of the present study was that it utilized an evidence-based candidate-gene approach. That is, the study was a direct test of a hypothesis derived from previous research. The advantage is that positive findings made in this way will tend to make biological sense, and that it allows for the discovery 
of statistically meaningful effects that are not as extreme as those required in theory blind approaches.

However, it should in this context be noted that the rs144551722 has no demonstrated functionality in itself. Instead, it was selected for study because of its close proximity to the MAOA-LPR region which is known to be functional $[7,8]$. The question whether future replications can validate our findings will of course be important since, experience shows that false positive findings in candidate gene studies have been a common feature in the literature. Such studies would of course also benefit from direct genotyping of the MAOA-LPR.

In summary, the results of the present study need additional replication, and a larger sample size, but tentatively suggest the possibility that MAOA-genotype might be associated with glioma development in males. If true, these findings open opportunities for further research concerning glioma tumourigenesis, possible therapeutic effects of MAO-inhibitors, and the possible predictive value of $M A O$ $A$-genotype as a diagnostic marker in males.

Acknowledgements Open access funding provided by Umea University. The PIs of each center in the Gliogene consortium is acknowledged and listed; Margaret R. Wrensch, Sara H. Olson, Michael E. Scheurer, Dora Il'yasova, Daniel Lachance, Georgina N. Armstrong, Lucie S. McCoy, Ching C. Lau, Elizabeth B. Claus, Jill S. Barnholtz-Sloan, Joellen Schildkraut, Francis Ali-Osman, Siegal Sadetzki, Christoffer Johansen, Richard S. Houlston, Robert B. Jenkins, Jonine L. Bernstein, Ryan T. Merrell, Faith G. Davis, Rose Lai,Sanjay Shete, Christopher I. Amos, Beatrice S. Melin, and Melissa L. Bondy. This study was supported by grants from NCI R01CA139020 (MB, BM) Northern Sweden Cancer foundation (RS), The Swedish Research, and the Swedish Cancer foundation and Umeå University hospital grant (BM).

Author contribution RLS (Hypothesis, writing of original draft and subsequent revisions); WY-YW and AMD (Data analysis of primary sample, critical revision of manuscript); ST and MLB (Data analysis of replication sample and critical revision of manuscript); BM (Hypothesis, revision of paper).

\section{Compliance with ethical standards}

Conflicts of interest None of the authors have any conflicts of interest to declare.

Open Access This article is distributed under the terms of the Creative Commons Attribution 4.0 International License (http://creativeco mmons.org/licenses/by/4.0/), which permits unrestricted use, distribution, and reproduction in any medium, provided you give appropriate credit to the original author(s) and the source, provide a link to the Creative Commons license, and indicate if changes were made.

\section{References}

1. Crocetti E, Trama A, Stiller C, Caldarella A, Soffietti R, Jaal J, Weber DC, Ricardi U, Slowinski J, Brandes A, RARECARE
Working Group (2012) Epidemiology of glial and non-glial brain tumours in Europe. Eur J Cancer. 48(10):1532-1542. https://doi. org/10.1016/j.ejca.2011.12.013

2. Altekruse SF, Kosary CL, Krapcho M, Neyman N, Aminou R, Waldron W, Ruhl J, Howlader N, Tatalovich Z, Cho H, Mariotto A, Eisner MP, Lewis DR, Cronin K, Chen HS, Feuer EJ, Stinchcomb DG, Edwards BK (eds) SEER Cancer Statistics Review, 1975-2007, National Cancer Institute. Bethesda, https://seer. cancer.gov/csr/1975_2007/, based on November 2009 SEER data submission, posted to the SEER web site, 2010

3. Melin BS, Barnholtz-Sloan JS, Wrensch MR, Johansen C, Il'yasova D, Kinnersley B, Ostrom QT, Labreche K, Chen Y, Armstrong G, Liu Y, Eckel-Passow JE, Decker PA, Labussière M, Idbaih A, Hoang-Xuan K, Di Stefano AL, Mokhtari K, Delattre JY, Broderick P, Galan P, Gousias K, Schramm J, Schoemaker MJ, Fleming SJ, Herms S, Heilmann S, Nöthen MM, Wichmann HE, Schreiber S, Swerdlow A, Lathrop M, Simon M, Sanson M, Andersson U, Rajaraman P, Chanock S, Linet M, Wang Z, Yeager M, GliomaScan Consortium, Wiencke JK, Hansen H, McCoy L, Rice T, Kosel ML, Sicotte H, Amos CI, Bernstein JL, Davis F, Lachance D, Lau C, Merrell RT, Shildkraut J, Ali-Osman F, Sadetzki S, Scheurer M, Shete S, Lai RK, Claus EB, Olson SH, Jenkins RB, Houlston RS, Bondy ML (2017) Genome-wide association study of glioma subtypes identifies specific differences in genetic susceptibility to glioblastoma and non-glioblastoma tumors. Nat Genet. 49(5):789-794. https://doi.org/10.1038/ng.3823

4. Ostrom QT, Kinnersley B, Wrensch MR, Eckel-Passow JE, Armstrong G, Rice T, Chen Y, Wiencke JK, McCoy LS, Hansen HM, Amos CI, Bernstein JL, Claus EB, Lachance DH, Lai RK, Merrell RT, Olson SH, Sadetzki S, Schildkraut JM, Shete S, Rubin JB, Lathia JD, Berens ME, Andersson U, Rajaraman P, Chanock SJ, Linet MS, Wang Z, Yeager M, Houlston RS, Jenkins RB, Melin B, Bondy ML, Barnholtz-Sloan JS (2018) Sex-specific glioma genome-wide association study identifies new risk locus at 3 p21.31 in females, and finds sex-differences in risk at 8q24.21. Sci Rep 8:7352. https://doi.org/10.1038/s41598-018-24580-z

5. Lan NC, Heinzmann C, Gal A, Klisak I, Orth U, Lai E et al (1989) Human monoamine oxidase A and B genes map to Xp 11.23 and are deleted in a patient with Norrie disease. Genomics 4:552-559

6. Brunner HG, Nelen M, Breakefield XO, Ropers HH, van Oost BA (1993) Abnormal behavior associated with a point mutation in the structural gene for monoamine oxidase A. Science 262(5133):578-580

7. Sabol SZ, Hu S, Hamer D (1998) A functional polymorphism in the monoamine oxidase A gene promoter. Hum Genet 103:273-279

8. Deckert J, Catalano M, Syagailo YV, Bosi M, Okladnova O, Di Bella D et al (1999) Excess of high activity monoamine oxidase A gene promoter alleles in female patients with panic disorder. Hum Mol Genet 8:621-624

9. Caspi A, McClay J, Moffitt TE, Mill J, Martin J, Craig IW et al (2002) Role of genotype in the cycle of violence in maltreated children. Science 297:851-854

10. Nilsson KW, Sjöberg RL, Damberg M, Leppert J, Ohrvik J, Alm PO, Lindström L, Oreland L (2006) Role of monoamine oxidase A genotype and psychosocial factors in male adolescent criminal activity. Biol Psychiatry 59(2):121-127

11. Tikkanen R, Auvinen-Lintunen L, Ducci F, Sjöberg RL, Goldman D, Tiihonen J, Ojansuu I, Virkkunen M (2011) Psychopathy, PCL$\mathrm{R}$, and MAOA genotype as predictors of violent reconvictions. Psychiatry Res 185(3):382-386. https://doi.org/10.1016/j.psych res.2010.08.026

12. Sjöberg RL, Ducci F, Barr CS, Newman TK, Dell'osso L, Virkkunen M, Goldman D (2008) A non-additive interaction of a 
functional MAO-A VNTR and testosterone predicts antisocial behavior. Neuropsychopharmacology 33(2):425-430

13. Meyer-Lindenberg A, Buckholtz JW, Kolachana B, Hariri AR, Pezawas L, Blasi G et al (2006) Neural mechanisms of genetic risk for impulsivity and violence in humans. Proc Natl Acad Sci USA 103:6269-6274

14. Passamonti L, Fera F, Magariello A, Cerasa A, Gioia MC, Muglia M, Nicoletti G, Gallo O, Provinciali L, Quattrone A (2006) Monoamine oxidase-a genetic variations influence brain activity associated with inhibitory control: new insight into the neural correlates of impulsivity. Biol Psychiatry 59(4):334-340

15. Sjöberg RL, Nilsson KW, Wargelius HL, Leppert J, Lindstrom L, Oreland L (2006) Adolescent girls and criminal activity: role of MAOA-LPR genotype and psychosocial factors. Am J Med Genet B 144:159-164. https://doi.org/10.1002/ajmg.b.30360

16. Nikulina V, Widom CS, Brzustowicz LM (2012) Child abuse and neglect, MAOA, and mental health outcomes: a prospective examination. Biol Psychiatry 71(4):350-357. https://doi.org/10.1016/j. biopsych.2011.09.008

17. Harro J, Oreland L (2016) The role of MAO in personality and drug use. Prog Neuropsychopharmacol Biol Psychiatry 69:101111. https://doi.org/10.1016/j.pnpbp.2016.02.013

18. Caragher SP, Hall RR, Ahsan R, Ahmed AU (2018) Monoamines in glioblastoma: complex biology with therapeutic potential. Neuro Oncol 20(8):1014-1025. https://doi.org/10.1093/neuonc/ nox 210

19. Baker SA, Baker KA, Hagg T (2004) Dopaminergic nigrostriatal projections regulate neural precursor proliferation in the adult mouse subventricular zone. Eur J Neurosci 20(2):575-579

20. Höglinger GU, Rizk P, Muriel MP et al (2004) Dopamine depletion impairs precursor cell proliferation in Parkinson disease. Nat Neurosci 7(7):726-735

21. Winner B, Desplats P, Hagl C et al (2009) Dopamine receptor activation promotes adult neurogenesis in an acute Parkinson model. Exp Neurol 219(2):543-552

22. Brezun JM, Daszuta A (1999) Depletion in serotonin decreases neurogenesis in the dentate gyrus and the subventricular zone of adult rats. Neuroscience 89(4):999-1002

23. Singh SK, Hawkins C, Clarke ID et al (2004) Identification of human brain tumour initiating cells. Nature 432(7015):396-401

24. Lee JH, Lee JE, Kahng JY, Kim SH, Park JS, Yoon SJ, Um JY, Kim WK, Lee JK, Park J, Kim EH, Lee JH, Lee JH, Chung WS, Ju YS, Park SH, Chang JH, Kang SG, Lee JH (2018) Human glioblastoma arises from subventricular zone cells with lowlevel driver mutations. Nature 560(7717):243-247. https://doi. org/10.1038/s41586-018-0389-3

25. Basu S, Sarkar C, Chakroborty D et al (2004) Ablation of peripheral dopaminergic nerves stimulates malignant tumor growth by inducing vascular permeability factor/vascular endothelial growth factor-mediated angiogenesis. Cancer Res 64(16):5551-5555

26. Sarkar C, Chakroborty D, Chowdhury UR, Dasgupta PS, Basu S (2008) Dopamine increases the efficacy of anticancer drugs in breast and colon cancer preclinical models. Clin Cancer Res 14(8):2502-2510

27. Björkblom B, Wibom C, Jonsson P, Mörén L, Andersson U, Johannesen TB, Langseth H, Antti H, Melin B (2016) Metabolomic screening of pre-diagnostic serum samples identifies association between $\alpha$ - and $\gamma$-tocopherols and glioblastoma risk.
Oncotarget 7(24):37043-37053. https://doi.org/10.18632/oncot arget. 9242

28. Wu JB, Shao C, Li X, Li Q, Hu P, Shi C, Li Y, Chen YT, Yin F, Liao CP, Stiles BL, Zhau HE, Shih JC (2014) Chung LW monoamine oxidase A mediates prostate tumorigenesis and cancer metastasis. J Clin Invest 124:2891-2908

29. Shih JC (2018) Monoamine oxidase isoenzymes: genes, functions and targets for behavior and cancer therapy. J Neural Transm 125:1553-1566

30. Kushal S, Wang W, Vaikari VP, Kota R, Chen K, Yeh TS, Jhaveri N, Groshen SL, Olenyuk BZ, Chen TC, Hofman FM (2016) Shih JC Monoamine* oxidase A (MAO A) inhibitors decrease glioma progression. Oncotarget 7:13842-13853

31. Amirian ES, Armstrong GN, Zhou R, Lau CC, Claus EB, Sloan JSB, Il'yasova D, Shikdkraut J, Osman FA, Sadetzki S, Johansen C, Houlston RS, Jenkins RB, Lachane D, Olson SH, Bernstein JL, Merrell RT, Wrensch MR, Davis FG, Lai R, Shete S, Amos CI, Scheurer ME, Aldape K, Alafuzoff I, Brännström T, Broholm H, Collins P, Giannini C, Rosenblum M, Tihan T, Melin BS, Bondy ML (2016) The glioma international case-control study: a report from the genetic epidemiology of glioma international consortium. Am J Epidemiol 183(2):85-91. https://doi.org/10.1093/aje/ kwv235

32. Kersey PJ, Allen JE, Allot A, Barba M, Boddu S, Bolt BJ, Carvalho-Silva D, Christensen M, Davis P, Grabmueller C, Kumar N, Liu Z, Maurel T, Moore B, McDowall MD, Maheswari U, Naamati G, Newman V, Ong CK, Paulini M, Pedro H, Perry E, Russell M, Sparrow H, Tapanari E, Taylor K, Vullo A, Williams G, Zadissia A, Olson A, Stein J, Wei S, Tello-Ruiz M, Ware D, Luciani A, Potter S, Finn RD, Urban M, Hammond-Kosack KE, Bolser DM, De Silva N, Howe KL, Langridge N, Maslen G, Staines DM, Yates A (2018) Ensembl genomes 2018: an integrated omics infrastructure for non-vertebrate species. Nucleic Acids Res 46(D1):D802-D808. https://doi.org/10.1093/nar/gkx10 11

33. Howie B, Fuchsberger C, Stephens M, Marchini J (2012) Abecasis GR Fast and accurate genotype imputation in genome-wide association studies through pre-phasing. Nat Genet 44(8):955-959. https://doi.org/10.1038/ng.2354

34. Howie B, Marchini J, Stephens M (2011) Genotype imputation with thousands of genomes. G3 (Bethesda) 1: (6):457-470. https ://doi.org/10.1534/g3.111.001198

35. Howie BN, Donnelly P, Marchini J (2009) A flexible and accurate genotype imputation method for the next generation of genomewide association studies. PLoS Genet 5(6):e1000529. https://doi. org/10.1371/journal.pgen.1000529

36. Delaneau O, Marchini J, Zagury JF (2011) A linear complexity phasing method for thousands of genomes. Nat Methods 9(2):179-181

37. Ou XM, Chen K, Shih JC (2006) Glucocorticoid and androgen activation of monoamine oxidase $\mathrm{A}$ is regulated differently by $\mathrm{R} 1$ and Sp1. J Biol Chem 281(30):21512-21525

Publisher's Note Springer Nature remains neutral with regard to jurisdictional claims in published maps and institutional affiliations. 